\title{
MISTRAL MISTRAL
}

Journal of Latin American Women's

Intellectual \& Cultural History

\section{The Little Tortoise}

\section{Marjorie Agosín (author)}

Alison Ridley (translator)

To cite: Marjorie Agosín. 2021. "The Little Tortoise." Translated by Alison Ridley. Mistral: Journal of Latin American Women's Intellectual \& Cultural History 1 (1): 25-38, https://doi.org/ 10.21827/mistral.1.37554 


\section{The Little Tortoise}

A Short Story by Marjorie Agosín

To Fernando and Isabel, my cousins

A note from the author:

When I visited my cousins Fernando and Isabel in Santiago de Chile, I also visited Manuelita the little tortoise. I always went when it was summer in the Southern Hemisphere and would find her among the flowers or sometimes eating vegetables. I would often take her in my arms and I felt very happy when I was with her. I asked my cousins about how this little tortoise came to live at their house and they told me what I tell here in this story-that a lady from the North of Chile brought her to them and that instead of money in exchange for Manuelita she asked for food. Manuelita is still alive and at my cousins' house, but I decided to change the end of the story. I always think that people should go back to their own surroundings. Exile is difficult for people, and animals also love the familiar. For this reason, in the story the little tortoise is returned to her native place. I finished writing this story a few months before the Pandemic. At the time of the global confinement, I thought of Manuelita often because tortoises always walk slowly-they love slowness and I have always believed that when they hibernate in winter they try to repair a troubled world. May this story bring peace and joy. More than anything, may we know that we can always return home, even if only in our imagination.

\section{CHAPTER ONE}

I remember it was a sunny day with clouds that came knocking at the door, heralded in by the wind. Some of the clouds even managed to sneak into the house leaving in their wake the pleasant chilliness for which they are so well known. Mamá, who was accustomed to walking from one end of the house the other doing this and that, stopped in her tracks that day and went out on the patio as though she had been called by a mysterious voice from another world.

There was a blue fence through which poppies were growing. Mamá approached the fence and began talking with someone who looked like a little old lady. But, from where I was hiding some distance away, she also looked like a little girl because she was really, really short. In my child's imagination I thought she might be an old lady and a little girl all rolled into one. The "old girl," a made-up character I pretended to be when I played with my friends, had finally arrived! The woman was carrying a black rose in her hand and in her bag she had an artichoke that was even blacker than the rose. When I squinted to see the bag a bit more clearly, the artichoke started to move! I jumped back, startled. But as I squinted some more, I realized it wasn't the artichoke that was moving, but something beneath it.

Mamá must have noticed the same thing because I heard her ask, "Señora, what do you have in your bag? It looks like it's moving." 
The old woman said something in a voice so low that her words got whisked up with the bits of cloud that the wind had blown onto the patio. Her voice was not of this world, but another, the make-believe one where I liked to play.

"I have a small gift for you, señora. It's a little tortoise that has just been born. I named her Manuelita."

My mother was taken aback. It wasn't every day that she got to meet a newborn tortoise, one that had barely shown its little head to the world.

"Are you really giving her to me, señora?"

"Of course I am... but I was wondering if you could you give me a little bread, or some rice, or a few poppy seeds in exchange for Manuelita. I see you have lots of poppies in your garden."

My mother looked at her thoughtfully and asked, "Where are you coming from so dressed up, señora? Your shoes are so pretty and new."

"Why thank you. I wanted to look my best for this very special day," said the old lady with a gleam in her eye.

Mamá always told me that poor people wear new shoes and smart clothes when they want to show respect to someone else. At that moment, she seemed confused and touched at the same time by the old lady's sudden appearance, her display of respect, and her unexpected gift. She placed her hand on the woman's shoulder in a reassuring way that seemed to say You are welcome here, señora. Thank you for choosing our house.

The old lady gave Mamá another radiant smile. 'I'm from the north. I'm old and my skin is all wrinkly from the sun of Antofagasta. I think the cold is why I have shrunk so much. I used to be quite tall, but now I'm tiny! I bet you were wondering at first if I was a young girl or an old woman. The truth is that I'm both at the same time: half girl and half old lady. And from living so long among the tortoises in the north I walk like them too, slowly, slowly... But, pretty lady, please accept this little tortoise. She is special and I have been looking for the right family to take care of her. I see a young girl hiding over there. Perhaps Manuelita could be hers. She's your daughter, isn't she?"

Mamá began signaling to me to come over to them. I was hiding behind the curtains where I liked to disappear from everyone else, especially when there was lots of noise in our house. There I became a princess or a fairy godmother with all of my favorite toys by my side. As a little girl I liked to daydream and become completely engrossed in things like the infinite and circular patterns of sea shells and the floral pattern on the curtains that I imagined, once opened, led to an exotic forest full of colorful flowers. When I realized Mamá was not going to rest until I came out, I ventured from my hiding place and went out on the patio. As I approached, I saw the old woman taking the little tortoise from her brown bag.

"Her name is Manuelita. Do you like her?" she asked me, showing me the little creature. I was instantly intrigued and I desperately wanted to hold her. Manuelita's head moved from side to side and up and down as though sometimes saying "yes" and other times saying "no." When the tortoise was finally placed in my outstretched hands, she looked up at me with her bright eyes and calmed down right away. Her little shell was warm to the touch. I fell in love with her on the spot.

My mom went inside to gather up some supplies for the old lady: a kilo of flour, one of rice, and some poppy seeds that the old lady immediately stashed in a half-hidden pocket of her skirt. Mamá asked her if she would remain in Santiago, and the old lady said she never quite knew where she was heading next. She said she would let the wind carry her where it wanted her to go and that there were always caring people who would offer her a place to stay. Eventually she would 
head back to the north, to her home and to all the other tortoises she cared for there. Then she slipped something into Mamá's hand and kissed her on the cheek. Without another word, she turned and, with her slow tortoise gait, began walking back down the path, slowly disappearing from sight like a mirage.

I never stopped to think why that old lady chose us, but I understood in my little-girl mind that questions about certain mysterious and beautiful things should remain answered. 


\section{CHAPTER TWO}

Back then, Manuelita was so small that she fit in the palm of one of my little-girl hands, but what was most interesting about her was her shell that looked a bit like a circular suitcase, a little container covered with tiny squares painted in different colors: browns and greens with copper highlights like the soil in the rocky desert where she came from in the north.

Back then I didn't know much about the geography of Chile, the country where I lived with Mamá, Papá, Abuela Mercedes, and my brothers and sister. I didn't know about its regions or its capitals; I only knew tidbits of information that I had learned in school, although I must confess that, when I was little, I thought school was where I went to play with my friends more than to learn. I had no idea why the place Manuelita was from was called the Great North. But when I held her in my hand and I looked at the colored veins in her shell, I imagined the hills in that place where the old lady who had brought Manuelita to me lived.

I would also picture in my mind what the inside of those hills must have looked like with their rich minerals that crisscrossed like tongues of burning lava streaming through the valleys until they reached the sea where they transformed into rocks that then became a place for snails, crayfish, enormous crabs, and perhaps other tortoises like Manuela, to live. The little pathways that she had on her back and the strange regions that were drawn there seemed to me like the perfect map of a Chile that was growing in my imagination. When I was with Manuelita, no place seemed too far away, not even the islands of Chiloé - the most remote islands of my country that are filled with orange parrots and magic - , or the highest heights of Aconcagua, or the salt flats of the Atacama desert, or the pampa on the most southern tip of my country. Everything flowed together in that marvelous map that Manuelita carried around on her back. That was how, with the passing years, I learned a type of geography that was much more expansive than the one I learned about in school. And today, whenever anyone asks me what the geography of Chile is like, I always answer thinking of my childhood friend, Manuelita. 


\section{CHAPTER THREE}

When Manuelita first came to live with us, Mamá suggested that she might prefer to live in the garden rather than be inside the house with us, and she was right! Manuelita liked the company of the hydrangeas, the tomato plants, the artichokes, and the carrots. My little tortoise seemed to enjoy walking slowly among the plants and chasing worms that inched forward at a snail's pace as though they were the masters of the garden. One thing Manuelita did not like in the garden were the poppies. In fact, she would avoid them and would never try to taste them. Perhaps the brightness of those flowers overwhelmed her, or perhaps they frightened her with that semihypnotic stare of theirs that makes them appear as though they have just emerged from a painter's dream.

Manuelita nibbled at a variety of yummy treats in the garden, but if they were not fresh, she would pass them by and not touch them. Even tortoises have their likes and dislikes, and their own unique way of being, I used to think while I watched her eat and stroll casually around. One of her favorite things to eat were cabbage leaves, especially if they were bathed in morning dew. She also liked carrots that were orange like the spring. Tomatoes... not so much, and cilantro... not at all. It seemed that anything that was too green was not her cup of tea.

In the summertime she was partial to watermelons, the juicy ones with the small seeds. And the thing she loved more anything else, even nap time, were peaches. We would place them on the ground among the hydrangeas and the carrots, and Manuelita would spend hours happily walking and eating in what I imagined to be her own personal forest. 


\section{CHAPTER FOUR}

When winter arrived, Mamá said something strange. "You need to put Manuelita away for a while." I did not understand, so she explained that Manuelita needed to take a really long nap. The actual word she used was "hibernate." I still didn't understand, so she told me that Manuelita had to do like the bears do in the winter - they go to sleep until spring.

I found a shoe box where my tortoise could sleep for the next several months - such a long time! One day when the cold seemed to seep into all the nooks and crannies of our house, I knew it was time for Manuelita to go to sleep in her magic box where she would have sweet dreams of the hydrangeas and the mysterious poppies until she woke up again in the spring.

She had only just arrived and now I had to put her away and let her go to sleep? It just didn't seem right. I didn't want to be without her for the whole winter. However, with Mamá's help, I understood that things that go away in the winter come back again in the spring. She told me that you only have to think about the thing that went away in the cold weather for it to come back again when it turns warm. I picked Manuelita up, gave her a hug, and kissed her pretty shell. Then I put her in the box that Mamá had made comfortable with some dried grass she had found on the patio. We put Manuelita, snug as a bug in a rug, in my closet where I could check on her from time to time to make sure she was okay. I would stare at her for long minutes trying to guess what she might be dreaming.

"I don't think tortoises dream, m'ija," Mamá told me as she stirred a pot of peach preserves with an enormous wooden spoon.

"Mamá, everything dreams, even tortoises," I replied with some authority. "I think Manuelita's dreaming of you stirring those preserves. You know how much she loves peaches. I bet she's dreaming of eating them when she wakes up in September." Mamá smiled at me as though she wanted to tell me many things at once with that single smile.

Throughout the winter my sister and I would sneak into the closet really quietly to look at Manuelita asleep in her shoebox. We did not want to wake her. Her shell was bright, as though it had a light inside of it. We would give her a gentle kiss and tell her about the peach preserves. She was always really still and even the wind seemed to die down when we were with her. It was as though the wind was also trying to be very quiet so as not to wake Manuelita from her sweet, peachy dreams.

Sometimes, after my sister had gone to play somewhere else in the house, I would spend a bit more time with my tortoise, admiring her and imagining how when animals and people sleep in the dark they are filled with the beauty and light of dreams. I would fetch my blanket and my feather pillow - the one my grandmother had brought me from another country far, far away-, set them down next to where Manuelita was sleeping, and lay down beside her. From observing her so much, I discovered that Manuelita had a glow all her own at night that illuminated my heart, especially in those long winter months when I longed to be out in the garden with her. We never spoke to each other, because we understood each other perfectly well without words. Sometimes I thought she moved one of her little feet, but she didn't really - she just slept and slept some more in her shoebox house that Mamá had painted blue.

I knew that when the jasmines were blooming and my father plucked their small flowers to put on our pillows, it would be time for Manuelita to wake up from her really long nap. I also knew that the first thing she would do would be to poke her sleepy little head slowly out of her shell. She would move really slowly for a couple of days because it takes tortoises a little while to recover from hibernating. 


\section{CHAPTER FIVE}

The first winter seemed to go by much more slowly than usual, kind of like the slow steps Manuelita would take when strolling around the garden. But then, one day, winter came to an end, and my tortoise started to wake up. She moved slowly, so slowly that her movements were barely perceptible. First she moved one of her little front feet, then the other. Then, finally, she began to peek her head out from under her shell. I thought that perhaps she would give me a big yawn, but that didn't happen. At first, she woke up as though in slow motion, but then, all of a sudden, she was fully awake. Once I had said hello to her, I picked her up to take her out to the garden. I could tell she had grown while she was asleep in her box because she didn't seem so small in my hands and the colors on her shell were brighter too. When I set her down on the patio, she made a slow beeline for the lawn where she seemed to dance gracefully with each blade of grass. I delighted in watching her go from one place to another with her slow tortoise elegance.

During the first two days that she was awake, she moved with the very elegance of slowness, so unlike the frenzy with which people move from one place to another without ever taking note of the important things around them. People, unlike tortoises, seem to wake up each day in a hurry. They guzzle down coffee and rush from their homes weighed down by bags and with their smart phones to their ears as though they are some kind of appendage. Papá says those things are supposed to bring us closer together, but it seems to me they keep us further apart. We should really try and learn something from our tortoise friends who take their time and enjoy life's small wonders and know when it's time to communicate and when it's time to take a good, long nap.

While Manuelita got bigger each year, other things gradually became smaller, like my granny, for instance. She was still with us back then and not in heaven where she is now. As she got older, she began to shrink, and her face became all wrinkly like the raisins Mamá used to put in her raisin cake. Of course, I would never have put Abuela Mercedes in a cake! She became so small that I was eventually able to fit her in Mamá's shopping basket and take her out into the garden where she enjoyed watching Manuelita stroll through the hydrangeas.

After a few years, Mamá started getting smaller too. But the strangest thing happened: as she got smaller, her voice got much, much louder. She got so loud that Manuelita would give a little start every time Mamá spoke. Soon the older members of my family started to look like little candles whose flames were slowly extinguishing. While they became smaller and older, Manuelita seemed to grow stronger and more confident. I was sure back then she would outlive us all.

In time, everything started to change. My Abuela Mercedes, who always wanted to go out in the garden to watch Manuelita, closed her eyes one day in the month of September - the month when we fly kites in Chile - and went to heaven. Whenever I would feel down about her passing, I would stroke Manuelita's shell and imagine Abuela in heaven planting flowers and preparing a place for Manuelita to join her when she was ready. You see it takes quite some time to be ready to go to heaven, because someone has to prepare a space for you there, just like I imagined Abuela doing for Manuelita. 


\section{CHAPTER SIX}

My siblings grew up, got married, and moved away from our childhood home. I, on the other hand, didn't want to grow up because I loved Manuelita and I wanted to stay home with her forever. One day, though, Mamá and Papá told me that I had to move away to get an education. I went to live in another country. Even though I wanted to take Manuelita with me, I had to leave her behind in the beautiful garden of my youth. Mamá promised she would look after her for me. I knew I was going to miss both of them with all my heart.

It is funny how you can fall in love with something so completely. For me, it was the little tortoise, but for others it might be a flower, or an elephant, or another person. Now I realize that I fell in love with Manuelita because she seemed small, delicate, and defenseless. She needed someone to care for her. The same thing happens to me with other animals as well, and the people I have lived with over the years have criticized me for sometimes seeming to care more about dogs and cats than people. I think what I do is right though, because those animals can't talk for themselves; they need someone to talk for them, to figure out what they need and want so they can be happy and live a good life.

After a few years of studying, I returned to Chile. I had missed so many things from my childhood, nebulous things that are hard to explain, but are part of who I am. For instance, I missed the ever-present fog that floats low to the ground and makes it hard to see, and the old clocks in my childhood home that marked the passage of time. The coming and going of the fog and the tick-tock of those clocks reminded me of who I once was and also allowed me to travel back to a different time in my mind, a time when I used to take Manuelita for walks in the park where little old ladies would sit watching the hours pass by. Sometimes Manuela would wander out of sight, but I always knew she was close by. Once in a while she would turn her tortoise head towards me so I could see her peeping through the grass. How I miss those simpler times. 


\section{CHAPTER SEVEN}

Summers came and went after my return, and with each new year the hydrangeas turned a deeper purple. Everything in my parents' garden grew: the basil, the freesias, and the irises. Manuelita loved to smell the flowers, but her favorite thing to do was eat. Apart from cabbage leaves, she really liked insects, especially the long skinny ones. I remember how she would eat her lunch out on the patio using her front legs like they were a knife and fork.

The hours, days, and years went by, and the trees grew so tall that it seemed they wanted to touch the sky with their branches. My parents became smaller and smaller still until they decided it was time for them to move from the big house into a smaller apartment. When they told me their plans, I panicked a bit. What would become of Manuelita? We couldn't take her to a place that had no garden, no insects, no stories... The poor thing would die of sorrow. She had made her home here; she knew it like the veining of her shell, and she had become so independent going this way and that in the garden. Even the neighbors knew her and would say hello when they saw her approaching the blue fence. The neighborhood dogs would greet her too and playfully sniff her shell.

Much to my relief, my parents put me in charge of taking care of their house and Manuelita. I knew that with Manuelita there with me I would not feel so alone. Although I must confess that, for me, it was never hard to spend long stretches of time without talking to anyone. I loved to read and transport myself to interesting places thanks to other people's stories.

After spending lots of time with Manuelita, I began to see the world as she saw it. I learned her unique pace in life and adapted it to my own way of being. In a way, the little tortoise was teaching me how to live life freely and not to let silly things bother me so much. 


\section{CHAPTER EIGHT}

Manuelita outlived my grandparents and my parents. Tortoises are extremely smart and that's why they have such long lives. Would she outlive me too? And, if that happened, who would take care of her? I lost sleep fretting over what would become of my tortoise should something happen to me. Manuelita, on the other hand, did not seem at all concerned. She just continued living her life as she always had, at her own pace, carrying around her house on her back, taking her long winter naps, and waking up in the spring ready to explore the world anew.

Each year her shell grew more beautiful and seemed to contain a world of stories. The veins grew longer and included within them my own story as well as my memories, including the scene of when Manuelita first arrived at our house. I believed that with her shell she was showing me all the things I had learned throughout the years. It was as though the lines on her back were a book in which everything I loved was inscribed.

In spite of all the love I felt for my little tortoise, the day came when I had to leave her once again. I had to move away to make a living. Even though she was just a small animal, leaving Manuelita a second time was one of the hardest, most painful things I have ever had to do. I would have happily stayed in my parents' house and continued to take care of Manuelita, but I had to leave in order to begin to live my own life and write my own stories.

I knew I would be gone longer this time... perhaps forever. Taking Manuelita with me was not an option. I was heading to a new country far, far away to the north. Moving her there would cause her more distress than I was feeling at the prospect of leaving her behind. So, with a heavy heart, I left her in the care of some new tenants who promised to take very good care of her and my parents' house.

With the passing of the years the thing I missed most about Chile, apart from my parents, was Manuelita. But I was lucky, because the tenants living in my childhood home would send me photos of my little tortoise, which helped me feel more at ease. Looking at those pictures of Manuelita walking through the grass and smelling the flowers made me happy.

A few years later, both of my parents passed away. I made a special trip to Chile to say goodbye to them and to visit with Manuelita. It was strange returning to my childhood home where all that remained were my memories, a few scuffs on the walls, and, of course, Manuelita. When I went out on the patio, I saw her sitting in the shade of a hydrangea. At first, she was not very effusive with me, but I didn't mind. I still felt like she had been waiting for me and was happy to see me. I approached slowly and leaned down to kiss her beautiful shell. It was only then that she began moving her feet and I swear she smiled at me when she moved her head from side to side. 


\section{CHAPTER NINE}

After that visit, I tried to return pretty much every year in September, because that was when Manuelita awoke from her long sleep, and it was also my favorite month of the year when I could enjoy the flying of the kites. I did not fly them myself because I never had the talent for it, but I delighted in watching others fly those colorful aerial banners in the blue Chilean sky. September is a month of new beginnings, the end of winter, and the promise of things to come.

When I visited my parents' house during those trips, the tenants' children would show me how they took care of Manuelita. They were so sweet with my little tortoise. They had kept her shoebox house in pristine condition for her yearly rests. As I watched the children play with Manuelita, I heard my mother's wise words in my head. Hija, all people are good at their core, but especially children. And I could tell she was right as the children talked non-stop about how they liked to look after and play with Manuelita. I had to laugh a bit, because I remembered how I too was so particular about taking care of Manuelita and making sure everything was just so when I was a little girl. Seeing the children with my tortoise always made me feel at peace, because I knew I had left Manuelita in the very best of hands.

During my visits home, I realized time and again that Manuelita carried within her, in her suitcase shell and in her being, all of the happy memories of our years together. She was a living reminder of that happy time. I didn't need to keep searching for those memories in strange cities, in places where they spoke languages I did not understand, in the silent trees, or in the copious snowfalls, in order to find a piece of home. All I needed to do was return in my mind to the place where those memories began - to my childhood home and to my Manuelita.

Many years later, tired of the work I had been doing, I decided to pack my suitcase and bid farewell to my co-workers who had never become my friends. They were more interested in looking at their smart phones and staring at the clock on the wall in anticipation of the end of the work day. I packed up my few belongings. I felt quite certain that no one would miss me and that no trace of me would remain in that cold country to the north. I somehow knew from one day to the next that it was my destiny to return home and be with Manuelita in her final years. 


\section{CHAPTER TEN}

Each time I returned home and saw the Andes mountains for the first time after a long absence, I was mesmerized by them. They seemed more impressive to me with every trip. Perhaps, as they say, nostalgia grows with time, and for that reason those mountains had such an impact on me. Apart from appearing magnificent, they also looked a lot like the dessert my grandmother and mother used to make called leche nevada. In English it's called "floating islands." It has a custard base that is covered with peaks of meringue sprinkled with cinnamon.

Even though my grandmother and mother are no longer with me, they come alive in my imagination each time I see the Andes or use a saying they used to use. You see, I believe the people who have passed on to another life continue to be real in our memories. For instance, sometimes when it rains, the droplets that stick to the window pane make a shape that reminds me of my father's face. I think in those moments that Papá has come back to visit with me and that each droplet of water is a message, a note of a song that Papá is playing on a piano nestled on a cloud in heaven.

I returned home for the last time in the middle of the long Chilean winter. When I arrived at my parents' house, I found Manuelita sleeping soundly. I noticed that her shoebox house was beginning to fall apart. It was time to buy her a new one. Perhaps I could get her one with a little door through which I could pass my hand in order to stroke her shell in the long winter months. Perhaps this time I could fill it with moss so she would have a comfy mattress on which to rest.

Being back home was wonderful. I felt instantly at ease. I recognized the bountiful stars in the clear Chilean sky and the familiar scents of my country. The timing of my return was also opportune as the tenants who had taken such good care of the house and Manuelita had decided to move on, leaving me in charge of my parents' home once more. My old room was just as I remembered it with its window that let in the brightest of lights in the morning and the bedside table atop which still sat my many books of poetry. As I sat on my bed that day, for a moment it was as though time had stood still. I imagined that I had never gone away and that my family was still waiting for me downstairs. It was a bittersweet feeling, one filled with love and sadness at the same time.

A couple of days later, Manuelita finally awoke. She recognized me right away. She stuck her head out from under her shell and kissed me with her delicate little tongue. For a long while I hugged her close. I imagined she was laughing, and that a small tear was gliding slowly down her tortoise cheek. Those are happy tortoise tears, I thought to myself, and began to laugh with her.

That spring I was so happy. Manuelita reminded me of the importance of serenity and stability. She taught me that simple acts like going out in the garden to breathe in the fresh air, or chatting with a neighbor and having a cup of tea, were the most important things in life. I quickly adjusted to my country's unique rhythm. My favorite thing to do, apart from spending time with Manuelita, was to listen to my neighbors recount the same stories I had heard so many times as a child. I loved hearing those tales over and over again, perhaps because I had learned to like permanence and the slowness of things, like the slow steps my tortoise took that had become even slower with time.

One day, several years later, I knew instinctively that the time had come to return Manuelita to the place where she was born; to the northern part of Chile where the nights are long and cold and where the noontime sun is intense. The geography of that place was always inscribed in the veins of Manuelita's shell. I knew I had to return her to her original home, to her original owner, for her to take the next step in her journey. 
And so it was that we left one morning on a slow green bus heading north. Although the bus was not moving very fast, the countryside seemed to pass by quickly. The verdant hills soon turned an ochre-yellow and orangey color. The color resembled the very first veins that appeared on Manuelita's shell when she was little. During the trip, the strangest thing happened. Each time the topography and the colors of the landscape changed, I would look down at Manuelita's shell and the colors there were exactly the same as the ones I was seeing through the window of the bus. It seemed like magic, like a sign of some sort; it was as though Manuelita was one with the geography around us. She was returning to her roots.

Despite the many years that had passed since Manuelita's arrival at our house, Mamá had saved the address of the lady who gave us the little tortoise when I was just a young girl. I remembered the lady passing something to Mamá on that magical day. Mamá had put the piece of paper with the address on it in a shoebox that was similar to the one in which Manuelita slept for so many winters.

Manuelita and I arrived in the town of her birth, tired, but happy. I couldn't find the house at first and had to ask the town's residents for directions. As soon as they saw me with the tortoise, they knew the house we were seeking and helped us find our way.

No sooner had I knocked at the door of the tiny house than a familiar face appeared before me. While her features had changed with time - as had mine - she was immediately recognizable as the lady who had given me such a precious gift so many years ago. I couldn't believe she was still alive. She was an old lady when she first came to my house. Now, she must be ancient, and I wondered briefly if she had been waiting for Manuelita to return before taking her next step in life.

As soon as she saw us, she said, "I knew you would come. I knew it the day I gave Manuelita to you when you came out from behind the curtains in your house to greet us. I also knew you would come because I have been dreaming of you both." She stared at me and at Manuelita for a long time, and in her eyes I could see peace and love. I knew I had done the right thing by taking my little tortoise back home. 


\section{CHAPTER ELEVEN}

The lady let us rest on a mattress that was set on the floor of her house next to a window through which we could see stars that seemed like enormous blue eyes in the sky. Manuelita and I fell asleep there hugging each other. The next day, Manuelita had recovered from the lethargy of the trip and I realized she liked to feel both the cold and the heat of her birth place because her shell began to blend in with the colors of the Chilean north: the ochres, yellows and an orange that looked like the sepia of old photos that capture memories forever.

The days passed by and soon I knew it was time for me to head back home and to leave Manuelita with her original owner. The thought of having to leave Manuelita forever made me so very sad. Nevertheless, I knew that everything had to return to its rightful place, just like we allwhen we feel death approaching - must return to the earth that sustained us so well in life.

I bade the lady farewell with a kiss on her weathered cheek. Then I picked up Manuelita and gave her a long, heartfelt hug, just like the first time I met her. I knew I would not see her again and a wave of sorrow washed over me. At the same time, though, I remembered thinking that love means that you never truly say goodbye, because our loved ones, in spite of everything, will always be with us. We only have to call their names for them to return in our memories.

I left the house and began slowly walking down the road that led to the bus stop. In spite of my sadness, I couldn't help but turn around to see Manuelita one last time. In the distance, I could see my little tortoise saying goodbye with her front legs as the lady held her gently in her arms. Then I saw Manuelita open her mouth and stick out her delicate tongue. It was as though she was telling me adiós. Goodbye my dearest friend. I will always love you, I told her in my mind, hoping she could hear me and understand.

When I returned home, my future was waiting for me: my work, my studies... in short, my life. Manuelita and I had lived together for so long, and although we had to part, my love for her endured. It was a slow and persistent love, like Manuelita's very movements and her unhurried and graceful way of walking. That was the most important lesson I learned from my sweet Manuelita: to gaze at the flowers in our garden without haste; to notice the smallest details of all the signs of life around us that we tend to take for granted without a second thought; and, to observe the world without the perpetual haste that leads us to nowhere. In short, she taught me to live life a paso de tortuga, at a snail's, or, in this case, a tortoise's, pace.

\section{THE END}

Translated by Alison Ridley 